\title{
Criteria for Appointment to and Promotion in Academic Rank
}

\begin{abstract}
To determine the status of librarians in the university community, what it means, and how it is determined, questionnaires were sent to one hundred major American academic institutions. Of eighty-seven respondents, seventy indicated that their librarians had academic status in one measure or another. There is need for clarification and standardization of practice. Criteria used for determining promotion are discussed, and a draft statement of policy in the matter is proposed.
\end{abstract}

$\mathrm{T}_{\mathrm{H}}$ HE MOVE to grant academic status to librarians has been the prevailing trend for a number of years and is now generally accepted, although the exact definition of academic status remains uncertain. Regardless of the institutional pattern, however, it is evident that academic status does carry with it certain privileges and obligations. ${ }^{1}$ Whenever obligations are involved, criteria must be formulated and applied to determine the degree to which the obligations are met.

This paper is an attempt to determine the criteria and the procedures commonly used for the evaluation of teaching faculty and the extent to which these criteria, or modifications thereof, are applied to librarians. From this basis, it may be possible to draft for consideration a statement of policy and procedure.

1Arthur M. McAnally, "Privileges and Obligations
of Academic Status," College and Research Libraries,
XXIV (March 1963), 102-108.

$M r$. Hintz is University Librarian, University of Oregon. This paper is one of a series of reports made by the Academic Status Committee of ACRL's University Libraries Section. The Committee invites comments from members of ACRL.
In order to gather information, a questionnaire was sent to the seventy-one academic libraries holding membership in the Association of Research Libraries plus a group of twenty-nine institutions, most of which were state universities. Replies were received from eighty-seven. Sixteen respondents indicated that librarians did not have academic status ${ }^{2}$ and one that "since practically all aspects of this subject are under intense study ... with a view to overhauling the whole plan, we deem it inadvisable to answer at this time." The material which follows, therefore, is based on replies from seventy institutions.

The pattern used in the questionnaire emerges quite clearly in the analyses of responses which follows, with perhaps one exception. One series of questions concerned procedures for reviewing recommendations for promotion with particular reference to the existence and use of a "personnel committee." Within the context of this series of questions "personnel committee" referred to an institutionwide committee to review all

\footnotetext{
2 In these sixteen libraries, however, academic status was held by some librarians in five, ranging from the director only to "approximately 43 per cent holding faculty status in one of the college faculties."
} 
recommendations for promotion regardless of the point of origin, as opposed to the device of internal school or departmental committees.

\section{Faculty Rank And Title}

The largest group of the respondents -twenty-six-reported that librarians held full faculty rank and title. In these institutions the criteria generally used for faculty appointment and promotion ranked as follows:

Success in teaching 25

Research and publication

Professional competence and activity

Service to the university

Creative work (artistic, dramatic, etc.)

Public service

Advanced degrees

Length of service

Effectiveness in administrative assignment

Evaluation of department members of higher rank

No general criteria but determined by department concerned

By department concerned in part

Twenty-two indicated that these criteria, or others in general use on the campus, were applied to librarians and fourteen that they were applied equally. Specific modifications listed were the following:

Doctorate not required for promotion

Greater stress on professional competence and nature of work performed

Less emphasis on publication

One respondent stated that all criteria were modified because of the nature of continuing assignments throughout a forty-hour week, a second that criteria are not rigidly applied "since the nature of our work and our work schedules preclude any great amount of formal teaching, research, or publication." Another made the cogent comment that since different persons apply criteria, they are not applied equally. This undoubtedly holds true elsewhere on the campus.
Seven of the respondents indicated a separate set of criteria based on the general ones (so much so that some checked both answers) in the nature of "almost the same," "additional distinctive criteria for librarians," "librarian's evaluation," or "greater weight to professional activities than to publication and research."

Practice varies in that twelve institutions had a campuswide personnel committee to review all recommendations for promotion and thirteen did not. A more important point is that in twentyone cases the procedure was the same for librarians and the general faculty. Five followed a different procedure; greater reliance was placed upon the recommendation of the library director and his key administrative personnel.

\section{Equivalent Rank}

Thirteen institutions reported patterns of equivalent rank; i.e., a Librarian L-LV or L-V series, corresponding to the customary academic titles of rank, such as instructor to professor.

In these institutions, the criteria generally used for faculty appointment and promotion ranked as follows:

Success in teaching

Research and publication

Creative work (artistic, dramatic, etc.)

Professional competence and activity

Service to university

Public service

Educational attainments

In applying these criteria, or others in general use on the campus, eight indicated that they were applied to librarians and four that they were applied equally. Specific modifications listed were the following:

Two master's degrees accepted in lieu of doctorate

Greater emphasis on professional competence and performance

Potential for long-term contribution to the institution 
Five respondents indicated a separate set of criteria. In general, these represent adaptations of general faculty criteria by expressing them in library terms.

Five of the institutions in this group reported the existence of a campuswide personnel committee to review all recommendations for promotion; seven did not. Eight of the thirteen libraries stated that the procedure followed was the same as for general faculty. Of the three which indicated a different procedure, the library administration played a greater part.

\section{Assimilated Rank}

Seven institutions reported a pattern of assimilated rank; i.e., library title with the rank of ... (catalog librarian with the rank of instructor). In these institutions, the criteria generally used for faculty appointment and promotion ranked as follows:

Success in teaching

Research and publication

Professional competence and activity

Creative work (artistic, dramatic, etc.)

Service to university

Public service

In applying these criteria, or others in general use on the campus, four indicated that they were applied in full to librarians and three others indicated that they were applied in part. On the question of equality of application, two felt that the criteria were applied equally, two in part, and three responded in the negative. Three of the respondents felt that the criteria applied to librarians were not separate from those in general use on the campus. Three felt that they were sufficiently modified as to make them distinct. Four institutions utilized a campuswide personnel committee; three did not. Two reported exactly the same procedure for librarians as for general faculty. Three reported mixed procedures and two reported different procedures. In the latter two the decision making power rested with the library administration.

\section{Variable Patterns}

The fourth group, comprising twentyfour respondents, reveals an almost bewildering array of patterns under the general umbrella of academic status. Sixteen of the group reported that they held neither full faculty rank and title nor assimilated rank. The remainder provided mixed responses or no response at all on these points. In other words, twenty-four groups of librarians with academic status do not fall into any readily definable classification.

The following are some illustrative schemes:

Librarians with formal teaching duties hold faculty rank and title with all others holding assimilated rank

Academic status and full faculty rank and title above instructor

Department heads are also assistant professors of library science. Non-department heads have not been assigned rank of instructor, although this could be done if there seemed any reason

No rank or tenure, but all other benefits, including membership on Senate, committees, etc.

No rank or membership on faculty, but faculty benefits apply. Some librarians have been elected to membership in a college or school faculty

Faculty status, but no formal rank. Voting power in faculty meetings and eligibility for election to Senate and other offices

No rank, but all privileges and responsibilities, such as serving on Senate and committees

All rights of faculty, except title and some committee memberships

Fully academic with review for advancement and appointment by Dean of Faculty. Librarians do not carry title unless they (1) hold a teaching appointment or (2) are "with the rank of ...." The librarian holds faculty rank and title; seven associate or assistant librarians are "with the rank of . . . ." In effect, all perquisites except rank, tenure, and sabbaticals 
Status has been used to include sabbatical leave, voting in faculty meetings, committee memberships. In short, everything except rank or rank equivalent, which is now being sought.

Among this group, the criteria generally used for faculty appointment and promotion ranked as follows:

Research and publication

Professional competence and activity

Service to university

Success in teaching

Public service

Creative work (artistic, dramatic, etc.)

Academic qualifications

No general criteria

15

14

12

11

7

In applying these criteria, nine indicated that they were applied to librarians and five that they were applied equally. Nine respondents stated that separate criteria were used. Eight of the respondents reported the existence of a campuswide personnel committee to review all recommendations for promotion. In one instance, the committee restricted its jurisdiction to teaching faculty only. Nine replied that the procedures for the promotion of librarians were the same, or very similar, to those for teaching faculty. Of the eight reporting a different procedure, the principal distinction rests in the greater role of the library administration.

\section{Application of Criteria}

The general tendency, repardless of the exact pattern for academic status, is to use the commonly accepted criteria for faculty evaluation although with modifications or special interpretations in some instances. Table 1 reveals some striking variations in application of faculty criteria, degree of application, and the evaluative procedures for promotion between the four groups of institutions.

Without attempting to read too much into this statistical exercise, it seems clear that institutions which have accorded full rank and title to librarians are evaluating them in terms of academic criteria to a greater extent than those institutions which follow a different pattern of academic status. This finding is substantiated by the fact that the "variant group," where academic status is poorly defined or not at all, makes by far the worst showing in the application of academic criteria. In some cases, in this group, the criteria are simply expressed in terms of a position classification (description) and suitability of the person for that position.

Since one of the major questions is "Should, how shall, or do, or can librarians meet the same criteria as teaching faculty?" it is pertinent to examine the criteria as they pertain to librarians before any consideration is given to the development of different criteria, or even substantial modification of existing ones. Many librarians are already meeting existing criteria, and there is no reason why more should not be able to do so, providing that their position descriptions called for them to do so, and if their work assignments were adjusted accordingly.

1. Success in teaching. This criterion requires special interpretation if it is to apply. Some librarians are engaged in formal classroom teaching, and many

TABLE 1

\begin{tabular}{|c|c|c|c|c|}
\hline Institutional Group & $\begin{array}{l}\text { Number of } \\
\text { Institutions }\end{array}$ & $\begin{array}{c}\text { Per Cent } \\
\text { Faculty Criteria } \\
\text { Applied }\end{array}$ & $\begin{array}{c}\text { Per Cent } \\
\text { Criteria Applied } \\
\text { To Same Degree }\end{array}$ & $\begin{array}{c}\text { Per Cent } \\
\text { Same Procedure } \\
\text { Followed }\end{array}$ \\
\hline $\begin{array}{l}\text { Full rank and title } \\
\text { Equivalent rank } \\
\text { Assimilated rank } \\
\text { Variant }\end{array}$ & $\begin{array}{r}26 \\
13 \\
7 \\
24\end{array}$ & $\begin{array}{l}84.6 \\
61.5 \\
50.0 \\
37.5\end{array}$ & $\begin{array}{l}56.8 \\
30.8 \\
50.0 \\
20.8\end{array}$ & $\begin{array}{l}80.8 \\
61.5 \\
16.7 \\
37.5\end{array}$ \\
\hline
\end{tabular}


more engage in informal teaching through their daily work with students in the library. Additional special examples are library orientation lectures and guest lectures on bibliographic resources in subject areas. A possible substitution here would be performance of specific duties assigned in the library. In view of the lack of emphasis placed on teaching as a criterion for advancement in most universities, this factor should not weigh too heavily against librarians.

2. Research and publication. This seems to be the major roadblock, particularly as it looms large in the promotion of teaching faculty. The fact that work schedules make research and writing for publication difficult for librarians is a stark reality. Some librarians find it possible to meet this criterion. Perhaps more would do so if it were clearly understood that it is expected of them. Conceivably, more personal recognition should be given to the bibliographical research performed by librarians in support of the research activities of others and in the development of research collections and to administrative, internal studies and reports.

3. Professional competence and activity. Demonstrated by performance on the job, by active participation in professional organizations (not limited necessarily to library associations), by evidence of continued growth, by mastery of bibliography, and by evidence of being an informed person in matters of educational philosophy and administration.

4. Service to the university. This may take the form of service on university committees, or working with student groups, such as foreign student organizations, honorary and professional societies, and others.

5. Creative work (artistic, dramatic). In addition to the obvious-creative writing, musical composition, painting, sculpture-participation in the performing arts, such as theatrical productions and musical performances, qualifies. The planning and preparation of some library exhibits involves considerable creativity.

6. Public service. As evidenced by service to the wider community.

\section{Formal Criteria}

Respondents were asked to describe criteria used for librarians if they were separate and distinct from those used for faculty in general and to send examples of rating forms or other materials used in the promotion process if they could do so conveniently. The fact that most of the respondents failed to do so suggests that formal statements of this nature are either lacking in most institutions or are not readily available in convenient form.

\section{The Need for Policy}

As pointed out at the beginning of this paper, academic status stands badly in need of definition. It is used to cover many differing circumstances, ranging from full faculty rank and title for librarians at one end of a spectrum to highly-structured position-classification situations which are considered academic because appointments fall within the jurisdiction of the personnel officer for academic affairs (dean of faculties, vicepresident for academic aftairs, etc.).

Clarification on this point could take one of three forms: full faculty rank and title, assimilated rank, or equivalent rank. Of these, the preferred pattern is that of full faculty rank and title as being most conducive to the development of a standard of librarianship which will best serve the educational, research, and scholarly needs of the academic community. This is based on the assumption that the contributions of librarians in academic libraries are so closely allied to those of academicians in all phases that at times they verge on the inseparable. Support for this thesis is found in the fact that the institutions now granting 
full rank and title to librarians are applying generally accepted academic criteria and procedures successfully, and to a greater extent than those institutions which do not grant such status.

\section{A Suggested Policy Statement}

Librarians should be accorded recognition proportionate to their qualifications, experience, and duties. A librarian should hold a graduate library degree or equivalent from a recognized institution, should participate in professional library organizations, and should perform duties of a professional nature. The determination of degrees to be regarded as terminal or appropriate should be vested with the library faculty, subject to the approval of the president. Proper recognition consists of faculty rank, tenure, and salary, and the procedure for advancement provided for other faculty members should apply to librarians. ${ }^{3}$

Criteria for advancement of professional library personnel include the following:

A. Teaching or instructional effectiveness shall be interpreted to mean the special kind of teaching, either group or individual, direct or indirect, that a librarian does. Such instruction may be judged by:

1. qualified student and faculty opinion;

2. informal opinion of colleagues;

3. effectiveness in the development and use of library resources for undergraduate, graduate, and research programs;

4. efficiency in the performance of library technical operations sup-

\footnotetext{
3 Since this will vary from institution to institution, no attempt is made to suggest a specific procedure here.
}

porting instructional and research programs.

B. Research or creative work should be rewarded, recognizing the severe limitations on such activities because of the demands on time and energy. This may be judged by:

1. publication of books, articles, reviews, and reports of 'a scholarly nature;

2. creative achievement involving musical composition, creative writing, original design, skillful production, and superior artistic performance;

3. preparation of high-level administrative studies;

4. mastery of bibliographic resources.

C. Professional competence and activity. This may be judged by:

1 . active participation in professional associations;

2. efforts for professional growth through further study;

3. study for advanced degrees;

4. knowledgeability in matters of educational philosophy and administration.

D. Service to university, including committee and administrative activity, is judged by:

1. service and leadership in the internal affairs of the university beyond the duties of the position held on the faculty;

2. supervision of library personnel;

3. demonstrated administrative ability and capacity for administration.

E. Public service includes participation on statewide committees, participation in professional activities in the state and nation, consultation, and community service. 